\title{
Technical Terminology in Greco-Roman Treatises on Artillery Construction
}

\section{Citation}

Schiefsky, Mark J. 2005. Technical terminology in Greco-Roman treatises on artillery construction. In Antike Fachtexte/Ancient Technical Texts, ed. T. Fögen, 253-270. New York: Walter De Gruyter.

\section{Published Version}

http://www.degruyter.com/cont/fb/at/detailEn.cfm?id=IS-9783110181227-1

\section{Permanent link}

http://nrs.harvard.edu/urn-3:HUL.InstRepos:3708557

\section{Terms of Use}

This article was downloaded from Harvard University's DASH repository, and is made available under the terms and conditions applicable to Other Posted Material, as set forth at http:// nrs.harvard.edu/urn-3:HUL.InstRepos:dash.current.terms-of-use\#LAA

\section{Share Your Story}

The Harvard community has made this article openly available.

Please share how this access benefits you. Submit a story.

Accessibility 
Forthcoming in: Proceedings of the XVI. Internationales Kolloquium des Studienkreises „, Geschichte der Sprachwissenschaft" (SGdS), ed. T. Fögen, W. de Gruyter 2005.

\title{
Technical terminology in Greco-Roman treatises on artillery construction
}

\author{
Mark J. Schiefsky
}

Harvard University/Max-Planck-Institut für Wissenschaftsgeschichte, Berlin

\section{Introduction}

This paper is concerned with the technical terminology of a well-developed ancient art or TÉXVฤ, the building of artillery engines. By technical terminology I mean the specific terms or phrases used by practitioners of an art or TÉ $\chi \vee \eta$ in connection with their professional activity. For my purposes in this paper, a term or phrase qualifies as a technical term if there is good reason to think that it was used in a reasonably standardized way by practitioners of a given

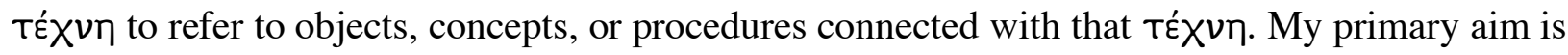
to consider technical terminology in relation to the knowledge that practitioners possessed and utilized in their professional activity.
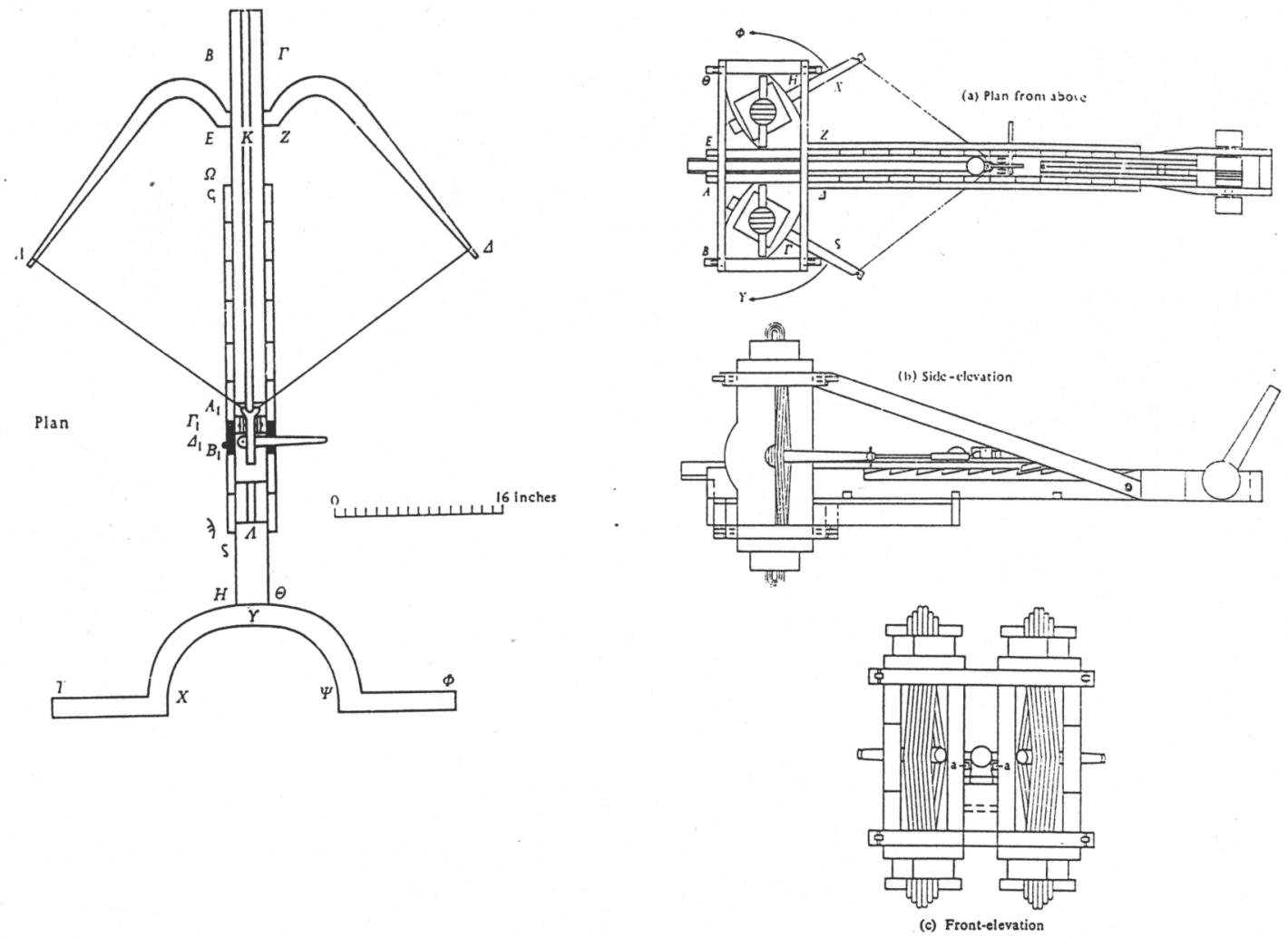

Figure 1: Non-torsion and torsion artillery (Marsden 1971: 47, 56). 
I begin with a brief description of the technical tradition reflected in the ancient texts on artillery construction (cf. Marsden 1969; Landels 1978: 99-132). While the use of the bow can be documented from the beginnings of Greek civilization, the invention of artillery engines may plausibly be dated to 399 BC, when the tyrant Dionysius of Syracuse brought together a large number of craftsmen with the specific goal of developing new military technology (Diod. Sic. 14.41; Marsden 1969: 48ff.). The earliest artillery was based on the idea of extending the power

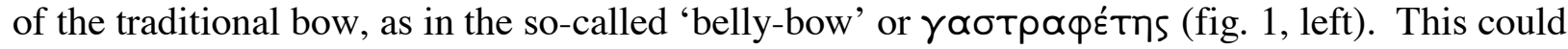
be drawn back by resting the curved beam (marked TXY $\Phi$ in the figure) against the belly; once ready, the bow would remain locked in position until the string was released by a sophisticated trigger mechanism. At some point in the mid-fourth century BC it was realized that the resilient properties of animal sinew or hair could provide much more power than the traditional bow. A typical example of this type of artillery engine (known as torsion artillery) is shown in fig. 1 on the right. Long strands of animal sinew were wound through the frame, and the arms of the engine were thrust into the bundle of strands (see especially the front elevation

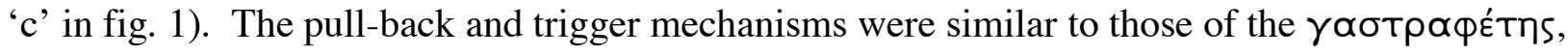
but had to be stronger because of the greater forces involved. After its invention in the midfourth century BC, torsion artillery spread rapidly through the Mediterranean world, and remained standard well into the Roman empire. Within torsion artillery, two types of engines

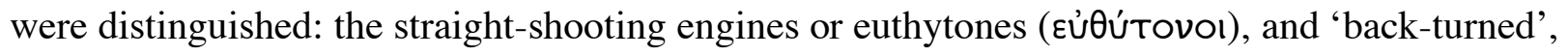
'V-spring' engines or palintones ( $\pi \alpha \lambda i$ ívovoı). As illustrated in fig. 2, these names were based on resemblance to the shapes of two different kinds of standard bow. The key difference between them was that the arms in palintone engines could be pulled back farther, making them more powerful. For this reason euthytones could shoot arrows only, whereas palintones could shoot both arrows and stones. 

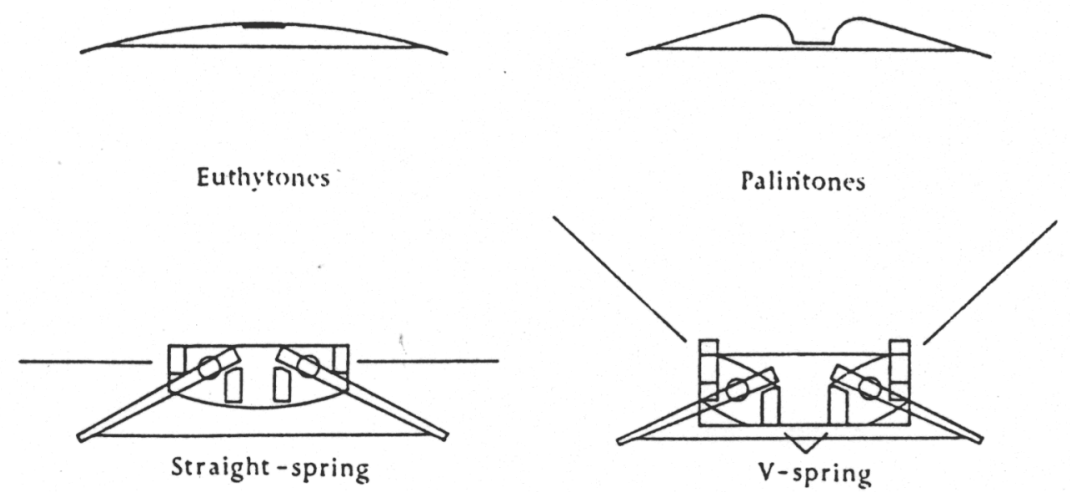

Figure 2: Euthytones and palintones. Marsden (1971: 45).

The construction of both torsion and non-torsion artillery depended on the existence of practitioners with highly specialized skills and knowledge. In particular, two types of information were of crucial importance. First, lists of dimensions were given, specifying the precise size of all components of an artillery engine down to the smallest detail. In the case of torsion artillery, the fundamental unit in which these dimensions were specified was the diameter of the hole through which the spring cords were strung. A larger hole meant a larger spring and thus a more powerful engine. Second, precise quantitative relationships were set out, correlating the size of the stone or the length of the arrow the engine was designed to shoot with the diameter of the spring hole. In the case of arrow-throwing engines, the diameter of the hole was specified as one-ninth the length of the arrow. For stone-throwers a much more complicated formula was developed: the diameter of the hole was obtained by taking the cube root of the weight of the shot, then adding one-tenth of that root. According to Philon of Byzantium, an important source to whom I will return below, these calibration formulae were discovered in Ptolemaic Alexandria as the result of an extensive program of systematic investigation and experimentation fostered by royal patronage. ${ }^{1}$

How was this knowledge transmitted? Oral instruction was no doubt of great importance. Philon's remarks about the patronage of the Alexandrian kings suggest a thriving community of researchers in close contact with one another; Rhodes too was an important center for the

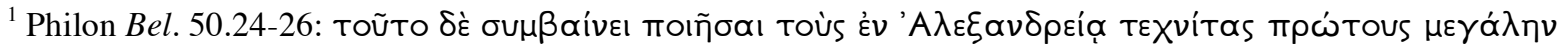

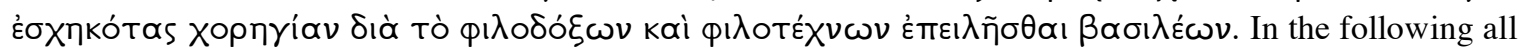
references to Heron and Philon are to the text of Marsden's edition (1971).
} 
development of military technology. ${ }^{2}$ But written texts also played an important role in the standardization and dissemination of the technical knowledge of artillery construction. ${ }^{3}$ Three sources in particular provide extensive information about the technical terminology employed in the discipline: two treatises by Heron of Alexandria and Philon of Byzantium (both entitled Belopoeica), and three chapters of the tenth book of Vitruvius' De architectura (10-12). In what follows I shall consider each of these sources in turn, with special emphasis on their treatment of technical terminology. How self-conscious are these authors about the technical character of the terminology that they use, and what can we infer from this about the audiences for which their texts are intended? What information do these texts provide about the range of this terminology, the degree to which it was standardized, and the way in which it developed? I shall conclude with some brief remarks on the relationship between technical terminology and technological and scientific development.

\section{Heron of Alexandria}

Heron of Alexandria's Belopoeica, probably written in the first century AD, describes the construction of various kinds of non-torsion and torsion artillery. These descriptions are set in the context of an account of how the latter developed out of the former as a response to difficulties arising from the need to achieve ever more powerful impact and longer range. A number of considerations indicate that the text's intended audience was not limited to practitioners of artillery construction. The Belopoeica opens with a striking passage arguing that the study of mechanics in general, and especially the branch of it known as artillery construction

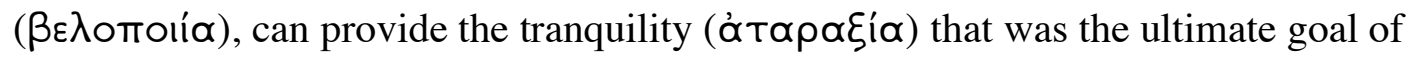

\footnotetext{
${ }^{2}$ Cf. Philon's remarks (Bel. 51.10-14) that the construction methods he reports in the Belopoeica are based on

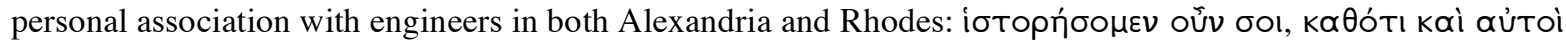

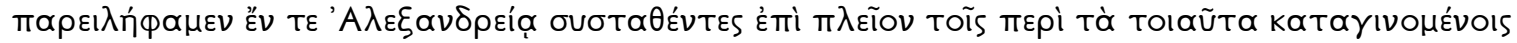

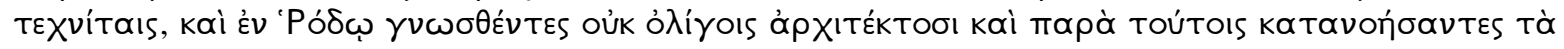

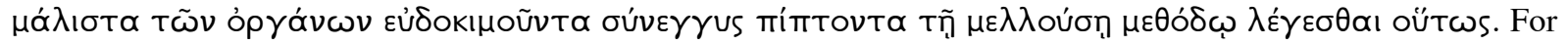
other references to the oral transmission of knowledge in Philon's Belopoeica see 68.1-2, 72.24-6. Cf. also Bel. 67.30, where Philon indicates that the constructional details of the bronze-spring engine invented by Ctesibius had

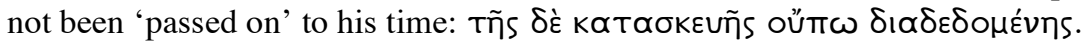

${ }^{3}$ Both Heron (Bel. 73.6 ff.) and Philon (Bel. 49.4-11) refer to numerous writers on the topic of artillery construction, without mentioning any by name.
} 
philosophical study (Bel. 71.1-73.5). ${ }^{4}$ Heron then goes on to take issue with predecessors who allegedly wrote only for those with extensive knowledge of the subject (Bel. 73.6-74.4):

\begin{abstract}
Writers before me have composed numerous treatises on artillery dealing with measurements and designs; but not one of them describes the construction of the engines in due order, or their uses; in fact, they apparently wrote exclusively only for experts. Thus I consider it expedient to supplement their work, and to describe artillery engines, even perhaps those out of date, in such a way that my account may be easily followed by everyone. I shall speak about the construction of complete engines and the individual parts thereof, about nomenclature, composition, cord-fitting, and, furthermore, their individual use and measurements -- after first remarking on the difference between the engines and the original development of each engine. ${ }^{5}$
\end{abstract}

The deficiencies criticized here are partly a matter of content (discussion limited to 'measurements' and 'designs'), partly of form or mode of expression (lack of an orderly, methodical, and clear exposition). In contrast to these authors, Heron promises a discussion of the construction, use, and terminology of the various engines that will present the subject in a way that is clear to anyone. The concern with nomenclature is signaled throughout the text by the frequent use of the verb $k \alpha \lambda \varepsilon \dot{\varepsilon} \omega$ to mark technical terminology. Often Heron describes the construction of a component of an artillery engine in general terms, and only then indicates that it is 'called' such and such, viz. by the practitioners of the TÉ $\chi \nu \eta$ itself. ${ }^{6}$ Moreover, in keeping

\footnotetext{
${ }^{4}$ While the sentiment si vis pacem, para bellum is a commonplace in ancient writings on military technology (Marsden 1971: 44), the opening of the Belopoeica is far more radical, in that it not only claims that mechanics is

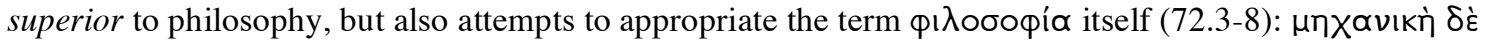

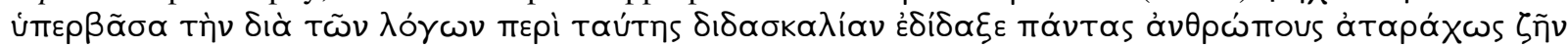

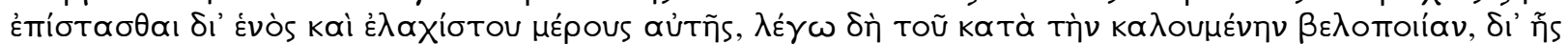

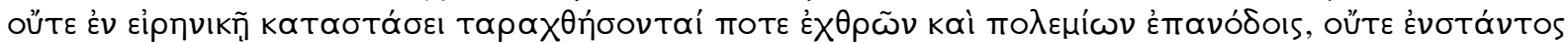

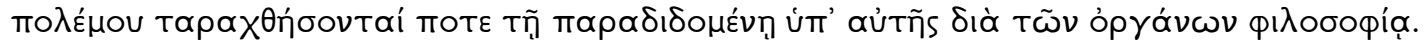

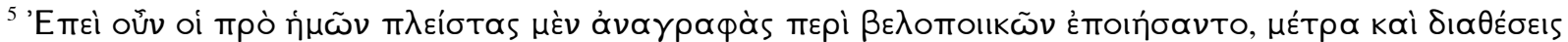

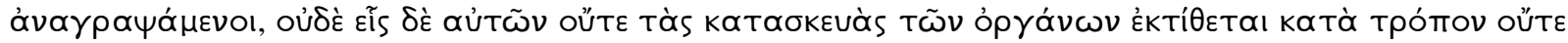

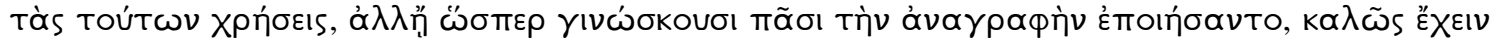

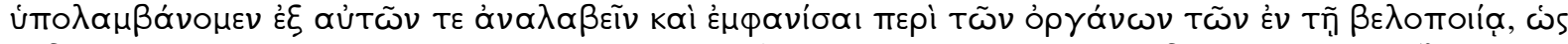

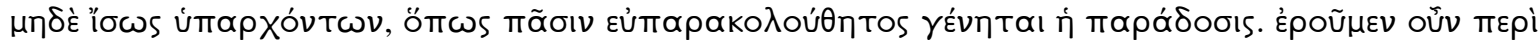

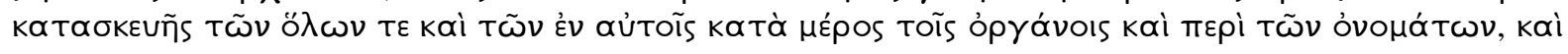

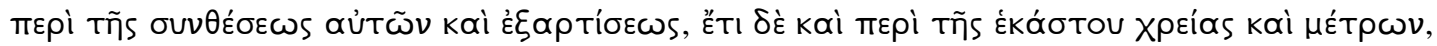

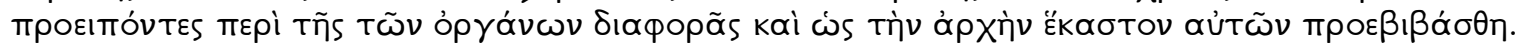
Translation Marsden (1971).

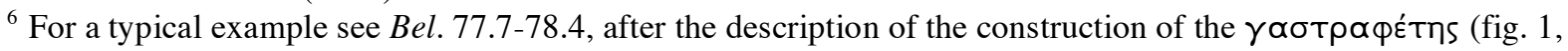
left): ékád

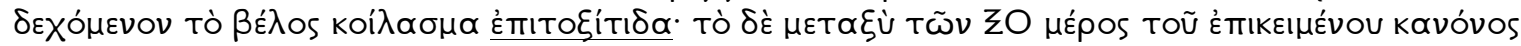

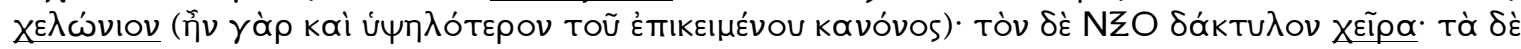


with the criticisms made in the above passage, Heron refrains from giving specific dimensions for the various parts of the engines that he describes. Such dimensional lists, as noted above, were central to the technical tradition of artillery construction and are an important feature of both Philon's and Vitruvius' accounts. But they are irrelevant if the goal is to communicate the general methods and terminology of the discipline. Finally, as the passage above suggests, there is good reason to suppose that the Belopoeica reflects the technological level of a time several centuries before Heron's own (Marsden 1971: 1-2); again this is understandable if the text is intended to communicate general principles rather than the latest in specialized design. A clear contrast with the Belopoeica in this regard is provided by another of Heron's treatises, the Cheiroballistra, which is indeed subject to many of the criticisms leveled in the above passage (Marsden 1971: 206-33). It describes the construction of a piece of artillery that was probably quite up to date in Heron's time, including precise specifications of dimensions, but in a way that could hardly be understood without extensive familiarity with both the methods and terminology of artillery construction. ${ }^{7}$

Heron provides extensive evidence of a specialized terminology for the different types of artillery engines (both torsion and non-torsion) and their parts. A sample of these terms, most of which are marked by the presence of $k \alpha \lambda \varepsilon ́ \omega$ in the text, is given in table 1 below. The range and detail of this terminology is striking. In the case of non-torsion engines, Heron's terminology

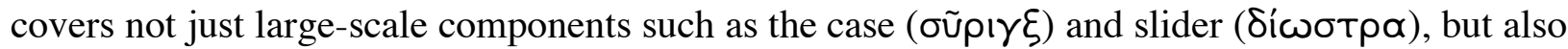

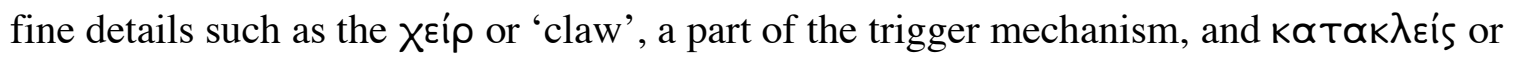
'clicker', a key component of the pull-back system. For torsion engines, we have a whole series of terms connected with the spring or tóvos and its frame or $\pi \lambda ı \theta \theta i o v$, such as $\pi \varepsilon \rho i ́ t \rho \eta т o \nu$ or 'hole-carrier' (the part of the frame containing the holes through which the spring cords passed),

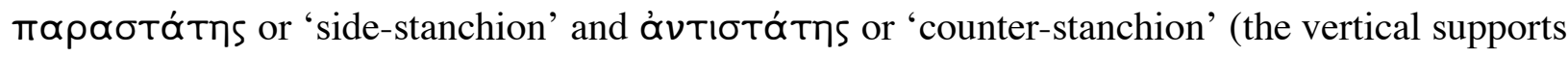

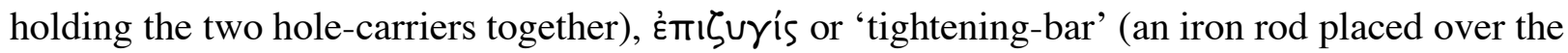
holes to hold the springs in place and to tighten them when necessary), Xolvikis (washer placed

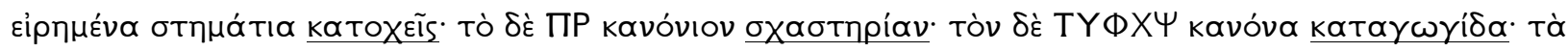

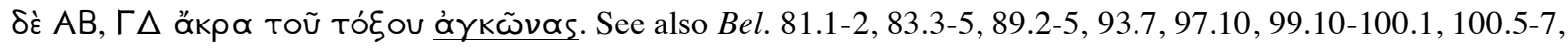
101.7.

${ }^{7}$ Marsden (1971: 208-9) draws attention to the similarity between Heron's cheiroballistra and the artillery engines depicted on the Column of Trajan. 
under the tightening bars), and úmó $\theta \varepsilon \mu \propto$ (a strengthening plate placed between the washer and hole-carrier). A further series of terms concerns the base or ßóols of the engine: these include

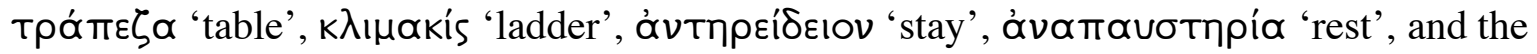
kapxńбıov or 'universal joint' on which the case of the engine was mounted. Finally we have a series of terms connected with the stretching of the spring cords, a crucial procedure in the construction and use of a torsion engine: '́vTóvıov 'stretcher' (a machine to perform the initial

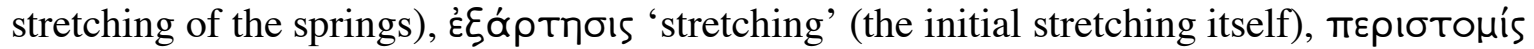
('clip' used in the stretching procedure), and દ̇тıотрофń ('extra twist' given to the spring cords to retighten them after some use).

Table 1: Heron's terminology

A. Non-torsion artillery:

\begin{tabular}{|c|c|}
\hline 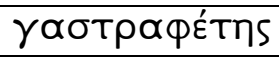 & belly-bow \\
\hline 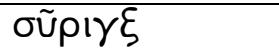 & case \\
\hline 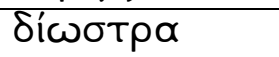 & slider \\
\hline ÉTITOKं̃TIS & groove \\
\hline 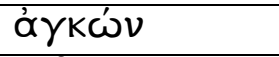 & arm \\
\hline 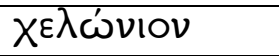 & block \\
\hline XEíp & claw \\
\hline K@TOXEÚS & holder \\
\hline 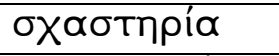 & trigger \\
\hline 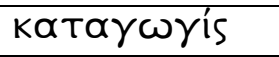 & withdrawal-rest \\
\hline 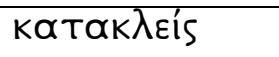 & clicker \\
\hline
\end{tabular}

\section{B. Torsion artillery:}

\begin{tabular}{|c|c|}
\hline EU่OÚTOVOV & straight-spring engine (also called бкортíos) \\
\hline 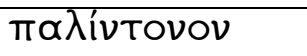 & V-spring engine (also called $\lambda_{\imath} \theta$ óßo $\lambda_{\circ}$ ) \\
\hline$\pi \lambda ı v \theta i ́ o v$ & frame \\
\hline Tóvos & spring; also called Évátovos, ர்HITóvıov \\
\hline XOIVIKís & washer \\
\hline 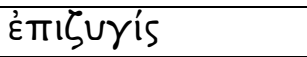 & tightening-bar \\
\hline Bóols & base \\
\hline 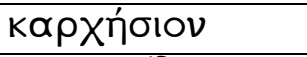 & universal joint \\
\hline 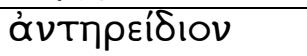 & stay \\
\hline 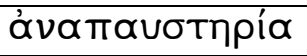 & rest \\
\hline
\end{tabular}




\begin{tabular}{|c|c|}
\hline 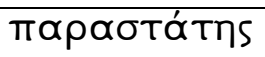 & side-stanchion \\
\hline óvTIOTótTS & 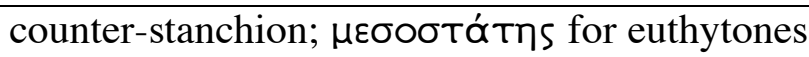 \\
\hline 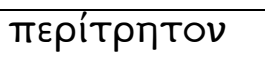 & hole-carrier \\
\hline บ̇тó $\theta \varepsilon \mu \alpha$ & strengthening plate placed under washer \\
\hline 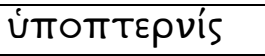 & heel-pad \\
\hline трIßEús & flange \\
\hline тра́ $\pi \varepsilon \zeta \alpha$ & table \\
\hline 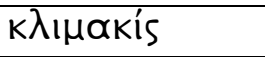 & ladder \\
\hline ÉVTÓVIOV & stretcher (machine for stretching spring cords) \\
\hline тврібтоні́s & clip (used in stretching spring cords) \\
\hline 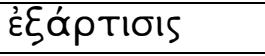 & initial stretching of spring cords \\
\hline غ́тाбтрофи́ & supplemental stretching by twisting \\
\hline
\end{tabular}

Heron's terminology includes a number of everyday words with a particular specialized

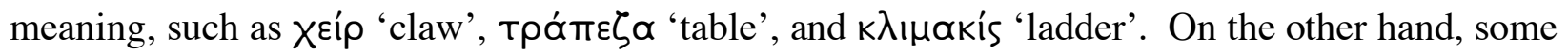
terms are new coinages that have no relevance outside the field of artillery construction. The term пврі́трптоv ('hole-carrier') is a case in point. Again, this refers to the beams on the top and bottom of the wooden frame that contained the holes through which the spring cords passed. As Hermann Diels was the first to suggest, the term пврі́трптоv is connected to the shape of the part to which it refers: in the hole-carrier, the main hole or трп̃ $\mu \alpha$ was surrounded by a ring of smaller holes into which the washer was fitted; hence the name пврі́трптоv, 'holes around' 8 Terms such as пврі́трптоv provide clear evidence of the importance of technological development in stimulating the creation of technical terminology: the new objects created in a TÉXVๆ called for new, specialized names. ${ }^{9}$ Heron sometimes remarks on the ways in which new terms were coined: euthytone engines, he says, are also called scorpions (бKopmíous) 'from the

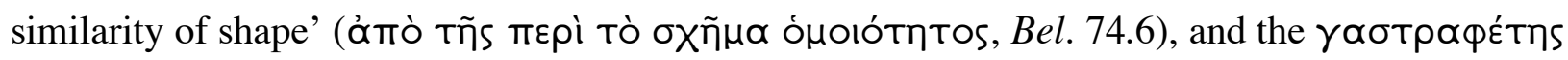
or 'belly-bow' got its name from the method used to draw it back, by resting it against the belly

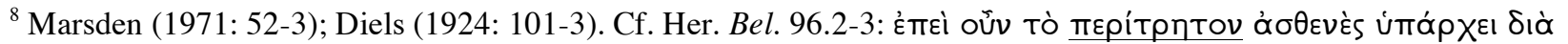
Tò Tாóv

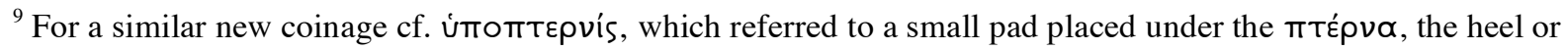

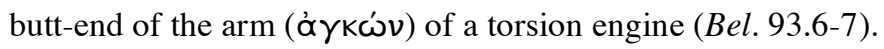




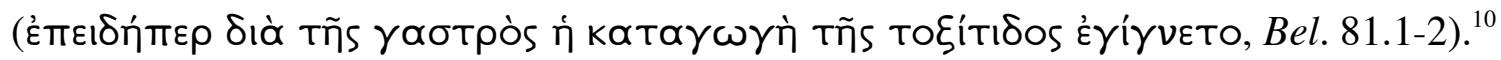

Finally, we may note that Heron draws attention to a certain amount of variation in the usage of particular terms; thus he remarks that some people call the single spring of a torsion engine Tóvos, while others refer to it as Évátovos or ínıтóvıov. ${ }^{11}$ But despite such variation, the overall picture conveyed by Heron's Belopoeica is of a stable terminology precisely matched to the fine detail and complexity of its subject matter.

\section{Philon of Byzantium}

Philon of Byzantium's Belopoeica, which probably dates from the late third century BC, originally made up the fourth book of an eight-book compendium of mechanical knowledge, the

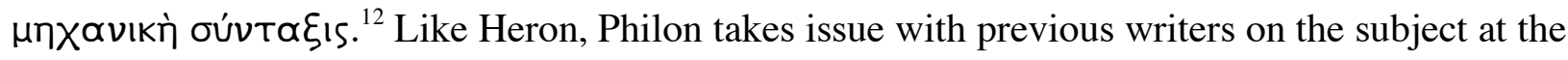
opening of his work:

Had it been the case that all who previously dealt with this section [sc. of mechanics] used the same method, we should have required nothing else, perhaps, except a description of the artillery designs which were standard. But, since we see that they [sc. previous writers] differ not only in the proportions of interrelated parts, but also in the prime, guiding factor, I mean the hole that is to receive the spring, it is only right to ignore old authors and to explain those methods of later exponents that can achieve the requisite effect in practice. ${ }^{13}$

Whereas Heron's stated purpose in the Belopoeica is to explain the procedures and terminology involved in the discipline of artillery construction to a reader not yet familiar with them, Philon is motivated by the need to resolve the disagreement among his predecessors and to present a

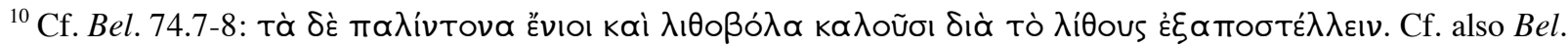

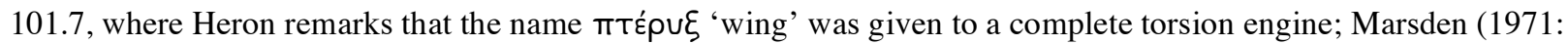
55) interprets this as a nickname, and translates 'Protector' (cf. LSJ s.v. III).

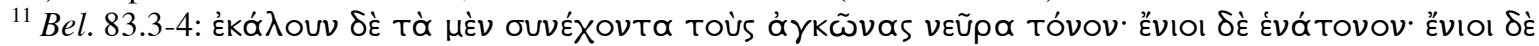
íuıtóviov. Cf. Bel.74.7-8 (quoted prev. n.).

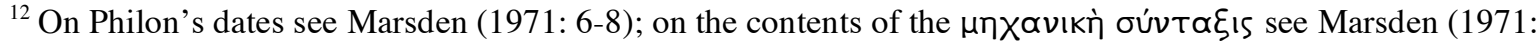
156n2). The Belopoeica is addressed to one Ariston, about whom nothing else is known (Bel. 49.1-4).

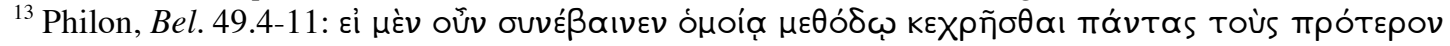

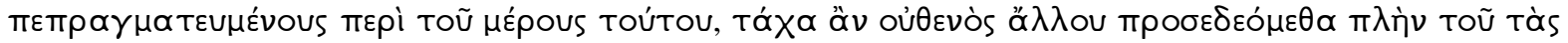

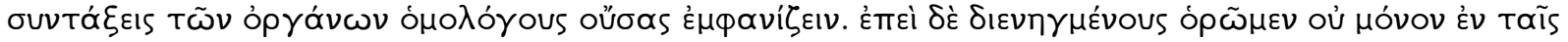

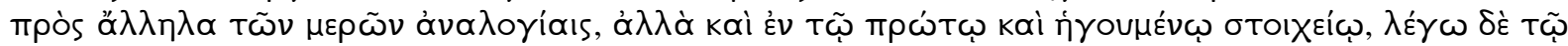

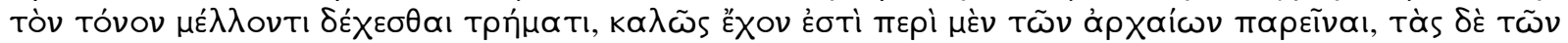


method that will enable a practitioner to attain a successful result. ${ }^{14}$ After some remarks on the discovery of the fact that the diameter of the spring hole is the 'prime, guiding factor' (Tò

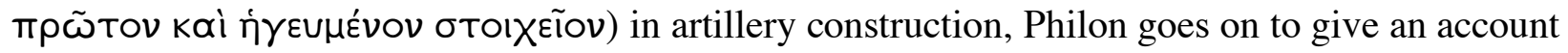
of the construction of standard-design torsion artillery of the sort that Heron describes; as noted above (n. 2), this account is explicitly based on personal association with engineers in both Alexandria and Rhodes. Philon begins with the method of calculating the size of the spring hole using the calibration formulae, then goes on to explain in detail the construction of the various parts of a torsion engine; he includes a complete dimensional list specifying the size of each part in units of the diameter of the spring hole (Bel. 53.8-55.11). At $56.8 \mathrm{ff}$. Philon goes on to make a number of criticisms of standard torsion artillery and to discuss several alternative designs, some of which he claims to have developed himself. Unlike Heron, Philon shows little concern to explain the terminology of artillery construction; rather, he seems to presuppose that his readers are already familiar with it. This suggests that his Belopoeica is intended for a somewhat more specialized audience that Heron's -- an impression confirmed by the presence of a table correlating the weight of shot of a stone-throwing engine with the diameter of the spring hole for a number of commonly used weights (Bel. 51.15-27). Such a table would enable a practitioner to avoid the extraction of a cube root, a necessary step if the calibration formula for stone throwers is applied directly. ${ }^{15}$

In general Philon's terminology is quite similar to Heron's. ${ }^{16}$ There are a number of minor differences (see table 2): cases in which Philon uses the same term as Heron in a slightly

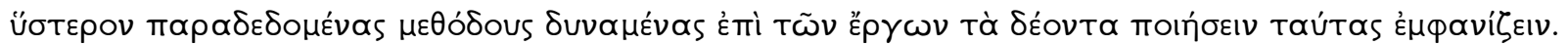
Translation Marsden (1971).

${ }^{14}$ The term $\mu \varepsilon \theta_{0} \circ \delta$ os occurs some 16 times in the Belopoeica, and Philo repeatedly insists on the need for a method;

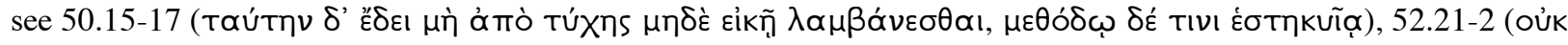

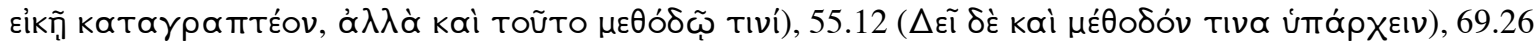

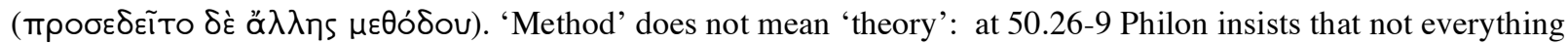

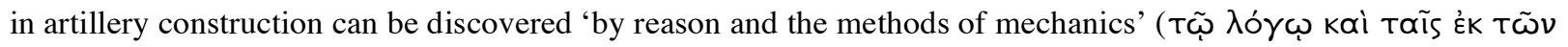

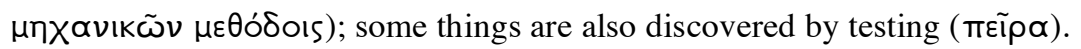

${ }^{15}$ Philon does, however, go on to set out a method for what is in effect the extraction of a cube root, by solving the traditional problem of doubling the cube (Bel. 51.28-52.19). Heron gives a very similar method at the end of his Belopoeica (114.8-119.2).

${ }^{16}$ Among the technical terms used in the same sense by Philon and Heron are: 'ó $\gamma \kappa \omega ́ v$ 'arm', Évтóvıov 'stretcher',

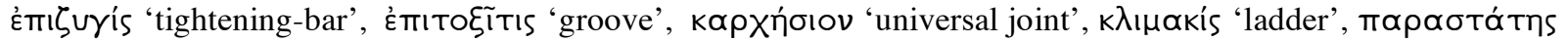

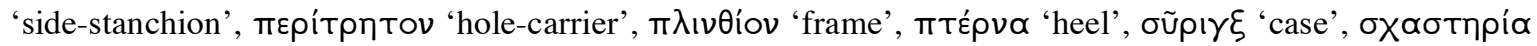

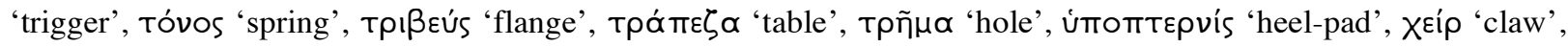
and Xoivikís 'washer'. 


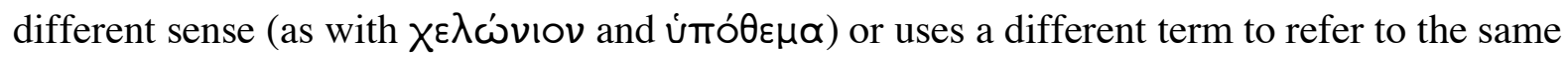

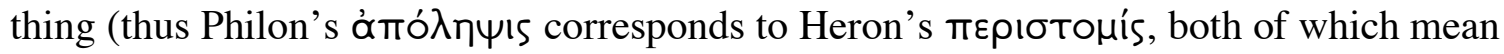
'clip'). ${ }^{17}$ With these differences in terminology go minor differences in technique on such

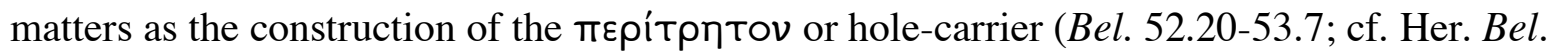
94.1-96.5). As Marsden has suggested (1971: 9), these differences can plausibly be ascribed to Philon's association with Rhodian engineers, in contrast to Heron's presumably Alexandrian connections. But despite these differences, the overall impression conveyed by a comparison of Heron's and Philon's terminology is nonetheless one of consistency and agreement.

Table 2: Philon's divergences from Heron

\begin{tabular}{|c|c|}
\hline 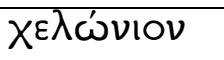 & 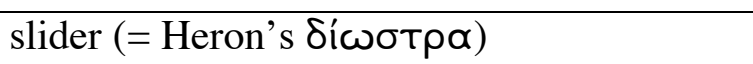 \\
\hline ن்ó $\theta \varepsilon \mu \alpha$ & strengthening plate fitting under hole carrier \\
\hline 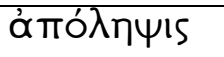 & 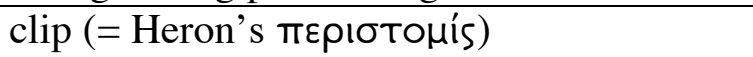 \\
\hline 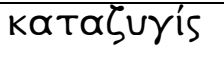 & 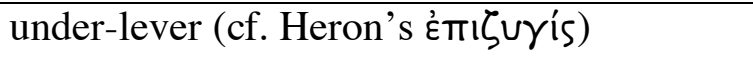 \\
\hline غ̇тाотрофи́ & supplemental stretching by twisting \\
\hline ர̇uITóviov & half of a torsion spring \\
\hline
\end{tabular}

The view must be qualified, however, when we come to Philon's criticisms and modifications of standard-design torsion artillery (Bel. $56.8 \mathrm{ff}$.). Here he proposes a number of significant terminological innovations in the course of an attempt to overcome certain perceived defects in the standard design. I shall consider three examples.

(1) A recurrent problem with torsion artillery was the tendency for the spring cords to slacken after continued use. This required re-tightening them, a process that was difficult to

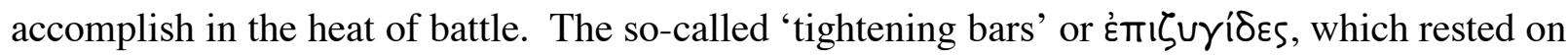
washers on top of the hole-carrier or пврі́трптоv, would be used to impart a twist to the spring cord and increase its tension. Philon criticizes this procedure strongly, claiming that such a twist is contrary to the nature of animal sinew and weakens it (Bel. 58.7-16):

In the heat of shooting and pulling-back, the spring experiences a slackening and needs tightening again. The range of the shooting deteriorates because of

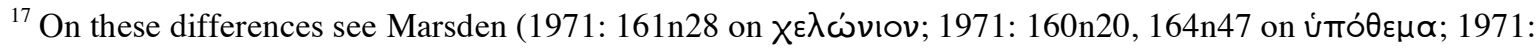

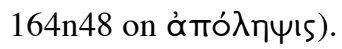


this relaxation. But those who wish to tighten it cannot apply the re-stretching

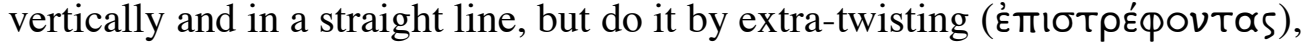
imparting an extra twist ('̇тıотофฑ́) unnaturally greater than is suitable...The engine loses its springiness because the strands are huddled up into a thick spiral and the spring, becoming askew, is robbed of its natural force and liveliness through the excessive extra-twisting (غ̇тıотрофท́). ${ }^{18}$

Philon therefore proposes a new kind of engine in which the tightening can be accomplished by means of wedges (fig. 3). In this design, the spring-cord is wrapped around an 'upper-lever' or

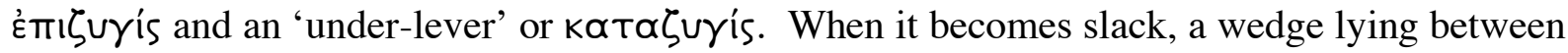
the two levers is driven in, thus pushing them apart and increasing the tension in the springs.

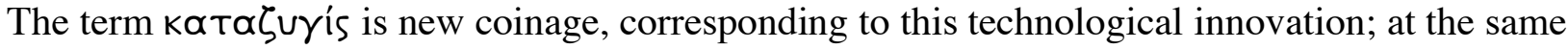

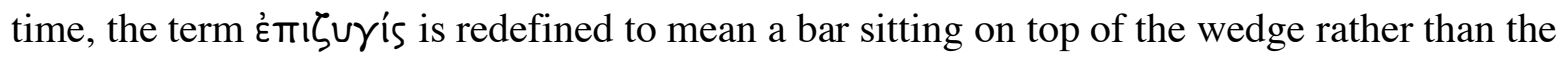
washer. $^{19}$

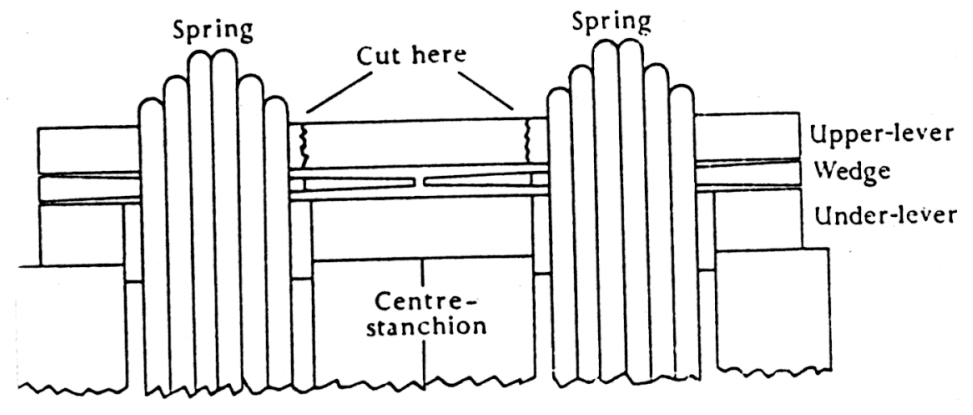

Figure 3: Detail of Philon's wedge engine (Marsden 1971: 174).

\footnotetext{
${ }^{18}$ Translation Marsden (1971).

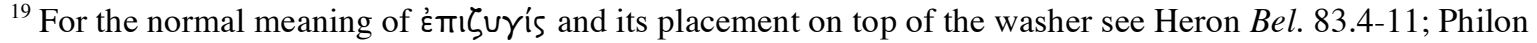
himself uses the term in this sense in discussing standard-design artillery (Bel. 53.23). The terminological innovation is signaled at Bel. 65.17. Having just explained the construction and placement of the $k \alpha \tau \alpha \zeta \cup \gamma i \delta \varepsilon s$, Philon

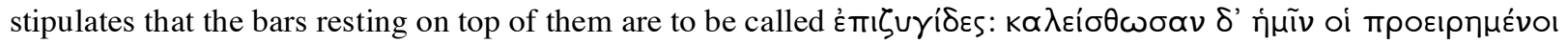

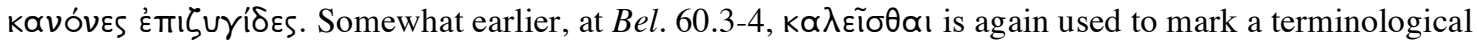

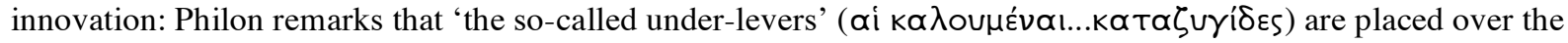

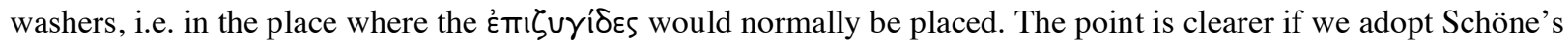

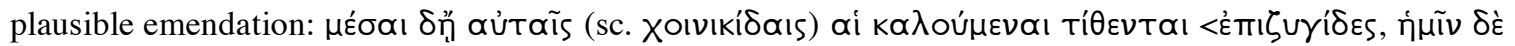

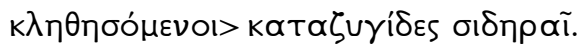


(2) In arguing for the superiority of his wedge engine, Philon also uses the term દ̇тıотрофи́ in a polemical manner. This is a technical term used by Heron for the 'extra twist'

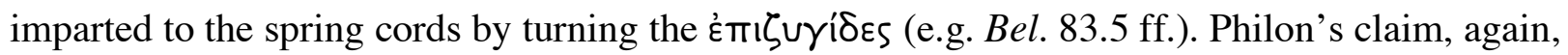
is that such a twist is unnatural, and that his own design makes it unnecessary. But at one point he claims that in his wedge engine the spring cords will receive a natural 'extra twist' (દ่тıотрофท́) by means of the wedges, even though no twisting is involved (Bel. 61.6-23):

I maintain that...I shall impart a very strong, natural extra-tension (દ่тюотрофи́), which will be enduring throughout and will in no way fail. I maintain that, while there is a tendency in continuous shooting, as we have shown, for relaxation of the spring to occur on account of frequent pullingsback, I can produce additional stretch immediately, not by extra-twisting (દ̇тाотрофท́) (for we have shown this to be injurious), but by stretching naturally and vertically and all the strands at once, just as they were originally stretched when the machine was being strung. That a more than suitable extratwist ('̇тіотрофń) produces great trouble, all others agree and we have clearly proved above. ${ }^{20}$

In the first sentence of this passage, Philon extends the range of the term Émı трофń to include all stretching of the spring cords; he then goes on to use the term in its more usual sense of "extra twist', where this is understood as harmful and contrary to the nature of the spring-cords. The effect of extending the meaning of غ̇тıотрофń in this way is to forestall a possible objection, viz. that the wedge engine provides nothing like the 'extra twist' of the standard design (Marsden 1971: 169n69).

(3) Finally, in discussing the so-called bronze-spring engine ( $\chi \propto \lambda$ ко́тоvоs) of Ctesibius of Alexandria (early third century BC), Philon uses the term íuıtóvıov to refer to one half of a spring cord, rather than a single spring cord as a whole (as Heron suggests was the standard usage, Bel. 83.3-4). ${ }^{21}$ Philon argues that for each arm of a torsion engine, only one of the

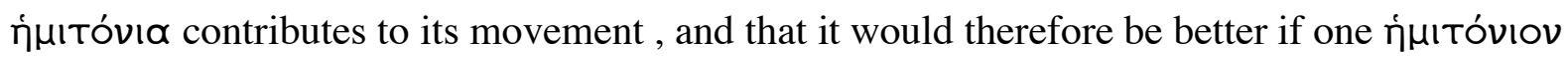
could be removed. But this is impossible, since then there would be nothing to hold the arm in place (Bel. 69.20-30). From such considerations, Philon suggests, Ctesibius was led to the

\footnotetext{
${ }^{20}$ Translation Marsden (1971).

${ }^{21}$ Once again Philon also adopts the standard usage when he is not discussing a technological innovation (Bel. 53.17).
} 
notion of employing springs constructed from bronze plates to provide the motive power to the arms. As well as being a remarkable assertion of the dependence of a technological development on theoretical considerations, this provides yet another example of the connection between technological development and shifts in terminology. ${ }^{22}$

\section{Vitruvius}

In chapters 10-12 of book 10 of the De architectura, Vitruvius discusses the construction of two types of torsion artillery: arrow-shooting engines or scorpiones and stone-throwers or ballistae. For the former he gives the standard calibration formula: the diameter of the hole is one-ninth the length of the arrow (10.10.1). In the latter case he refrains from giving the exact cube root relation, but instead provides a list correlating sizes of shot with the corresponding spring hole diameters translated into Roman units of measure (10.11.3); this, he says, is to make it possible for practitioners without knowledge of geometry to construct artillery engines even in the desperate circumstances of war. ${ }^{23}$ Vitruvius gives detailed lists of dimensions for both scorpions and ballistae; these are similar to Philon's, though they also reflect a number of technical improvements made in the intervening centuries (Marsden 1969: 41-7). Vitruvius claims to have knowledge of artillery both from teachers (praeceptores) and his own experience (10.11.2); according to his own account in the preface of the De architectura, he served Octavian as a military engineer concerned with the construction and repair of scorpions and ballistae. ${ }^{24}$ The impression that on the subject of artillery Vitruvius is writing as an expert and for experts is confirmed by the absence of any explanatory remarks on technical terminology in these chapters;

\footnotetext{
${ }^{22}$ For a further example of a technological modification based on theoretical considerations cf. Bel. 59.30-1, where Philon explains that in his wedge engine the spring cords 'do not converge, but run parallel' (Toùs Tóvous $\mu$ ì

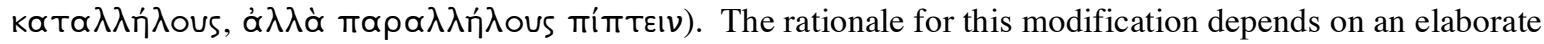
analysis of the arms of the engine as levers working at a mechanical disadvantage (59.11 ff.). The attempt to draw on a precise distinction between $\kappa \alpha \tau \alpha \dot{\alpha} \lambda \lambda \eta \lambda$ os and $\pi \alpha \rho \alpha \dot{\alpha} \lambda \lambda \eta \lambda$ os reflects the kind of concern with terminological precision that we have noted elsewhere in Philon's text.

${ }^{23}$ Vitr. 10.11.2: Itaque ut etiam qui geometricen non nouerunt habeant expeditum, ne in periculo bellico cogitationibus detineantur, quae ipse faciundo certa cognoui quaeque ex parte accepi a praeceptoribus finita exponam. Cf. 10.11.1: Igitur de ratione earum (sc. ballistarum) non est omnibus expeditum, nisi qui geometricis rationibus numeros et multiplicationes habent notas.

${ }^{24}$ Vitr. 10.11.2 (quoted prev. n.); Vitr. 1, praef. 2: Itaque cum M. Aurelio et P. Minidio et Gn. Cornelio ad apparationem ballistarum et scorpionum reliquorumque tormentorum refectionem fui praesto et cum eis commoda accepi, quae, cum primo mihi tribuisti recognitionem, per sororis commendationem servasti. Though Marsden (1971: 3-5) is inclined to doubt that Vitruvius' chapters on artillery are based on his personal experience, he nonetheless concludes that 'Vitruvius' designs for catapults and ballistae were right up to date, incorporating important modifications introduced between Philon's time and his own' (1971: 5).
} 
they are clearly intended for a reader thoroughly familiar with the technical discourse of artillery construction.

A striking feature of Vitruvius' account of artillery is the extent to which he makes use of Greek terms without providing any gloss on their meaning or drawing attention to linguistic borrowing (table 3A). In the case of some of these terms Vitruvius' usage deviates from that of

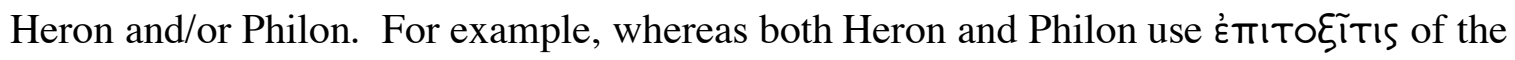
'groove' in which the arrow is placed (Heron Bel. 77, 79; cf. Philon Bel. 73, 75), Vitruvius uses epitoxis of the 'claw' of a trigger-mechanism ( $\chi$ Eí $\rho$ in the Greek sources). ${ }^{25}$ For Vitruvius the

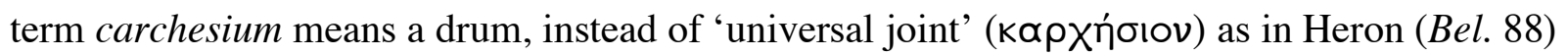
and Philon (Bel. 74). In 10.10.5 Vitruvius refers to the posterior minor columna, quae graece

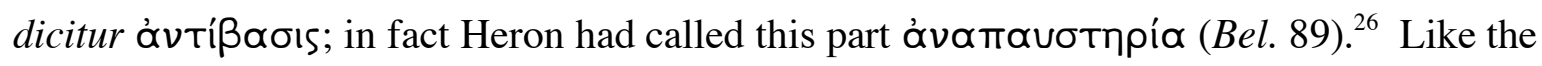
discrepancies between Heron's and Philon's terminology noted above, these differences probably reflect Vitruvius' association with particular engineering traditions. ${ }^{27}$ While some of the Greek terms used by Vitruvius display a certain amount of variation in usage, this variation is not greater than that present in the Greek sources themselves. Thus Vitruvius sometimes uses

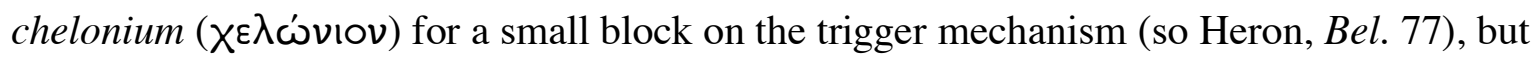
sometimes for the slider itself (Philon, Bel. 54). ${ }^{28}$ In the case of some Greek terms Vitruvius supplies an explanatory paraphrase or gloss (table 3B). Yet even here we have a Greek term (peritretos) whose meaning is assumed to be familiar to the reader elsewhere in the text (10.11.4), and a case in which one Greek term is used to specify the meaning of another (basis,

\footnotetext{
${ }^{25}$ Heron Bel. 78, 100, 111; Philon Bel. 68.

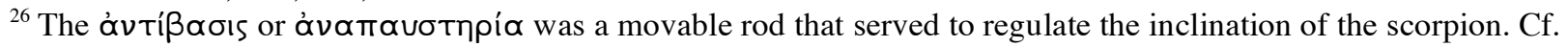
Vitr. 10.11.9, where antibasis refers to the 'counter-base', or stationary piece that is placed opposite the base in a ballista.

${ }^{27}$ See Marsden (1971: 4-5) on the possibility that Vitruvius' account is based on the writings of a single Greek engineer, Agesistratus.

${ }^{28} \mathrm{Cf} .10 .10 .5$, where chelonium refers to a small block that serves as a stop for the posterior minor columna or

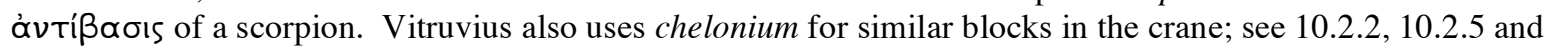
Callebat / Fleury (1995: 310). The wide range of meanings is hardly surprising, since $\chi £ \lambda \omega$ viov could be applied to anything that resembled a tortoise shell (the term's basic sense); cf. Her. Bel.93.7, where it refers to a 'pad' meeting

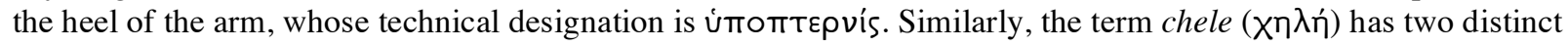

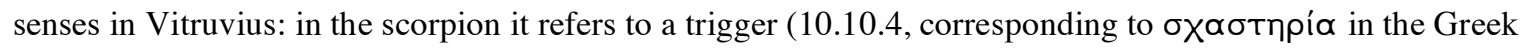

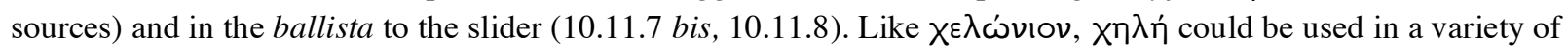
ways, all of them connected with the basic sense of an animal's hoof or claw; cf. Callebat / Fleury (2003: 233). For explicit indications of terminological variation in Vitruvius' account cf. 10.10.3 Regularum, quas nonnulli bucculas appellant...; 10.10.3 uocitatur scamillum, seu, quemadmodum nonnulli, loculamentum.
} 
quae appellatur ĖoXápa 10.11.9). In the case of chele and chelonium, Vitruvius gives a Latin gloss only for certain usages ('trigger' and 'pillow' or 'bolster', respectively; cf. n. 32 above); the meaning 'slider' for $\chi \eta \lambda \eta$ is assumed to be familiar to the reader at 10.11.7 (Ex his dentur duae partes ei membro, quod Graeci $\times \eta \lambda \eta \dot{v}$ vocant). ${ }^{29}$ In light of this, the passages in which Vitruvius expands on the meaning of a Latin term using a phrase of the form 'a, which in Greek is called $\beta^{\prime}$ (table 3C) are best interpreted not as attempts to clarify the meaning of Greek terminology in Latin, but rather as efforts to make the reference of the Latin phrase in question clear and unambiguous by giving the precise Greek equivalent. This is certainly the case with the expressions ei membro, quod Graeci $\chi \eta \lambda \eta \dot{v}$ vocant (10.11.7); similarly in the case of cuneoli

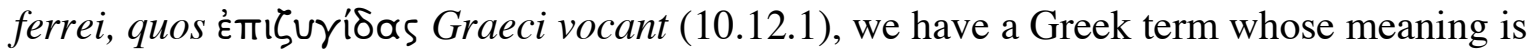
assumed to be familiar to the reader on its first occurrence earlier in the text (10.11.4: Foramen autem oblongius sit tanto quantam epizygis habet crassitudinem). The phrase posterior minor columna hardly qualifies on its own as a technical term with an unambiguous reference; moreover both scutula and canaliculus are used by Vitruvius in new senses, which are made

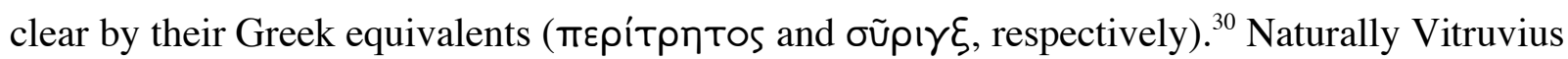
does employ a number of Latin terms without giving any Greek equivalents (table 3D). But these tend to be either straightforward translations of a corresponding Greek term (such as

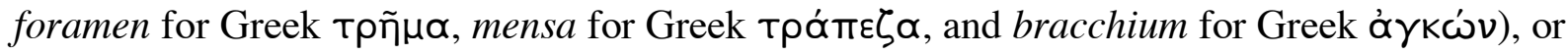
terms whose meaning is reasonably self-evident (such as antefixum, subiectio, or canalis fundus). Thus, despite the fact that artillery had been introduced into the Roman world several centuries before the time at which Vitruvius wrote, his account suggests that its terminology remained thoroughly Greek. ${ }^{31}$

\footnotetext{
${ }^{29}$ On the choice of reading here ( $\chi \eta \lambda \eta \dot{v}$ rather than the $\chi \varepsilon \lambda \omega \dot{v}$ ıov preferred by some editors, for the MSS chelon) see Callebat / Fleury (2003: 233).

${ }^{30}$ Both scutula and canaliculus are classified by Callebat and Fleury $(1995: 329,334)$ as 'mots de sens nouveau'. For further examples from other Latin authors of the expression 'a, which the Greeks call $\beta$ ', and a similar evaluation of their significance as reflecting a desire to achieve precision and clarity see Fögen (2002: 264-5, 271). ${ }^{31} \mathrm{Cf}$. the introduction to the discussion of harmonic theory at De arch. 5.4.1: Harmonice autem est musica litteratura obscura et difficilis, maxime quidem quibus Graecae litterae non sunt notae. quam si volumus explicare, necesse est etiam graecis verbis uti, quod nonnulla eorum Latinas non habent appellationes.
} 
Table 3: Vitruvius' terminology (10.10-12)

A. Greek terms used without explanatory gloss:

\begin{tabular}{|c|c|}
\hline epitoxis & “claw' (Heron's Xeíp) 10.10.4 \\
\hline parastata & $\begin{array}{l}\text { 'side-stanchion' } 10.11 .5 \text {; cf. parastatica } 10.10 .2 \text {, } \\
10.11 .6 \text { and parastas media } 10.10 .2,10.10 .3\end{array}$ \\
\hline carchesium & 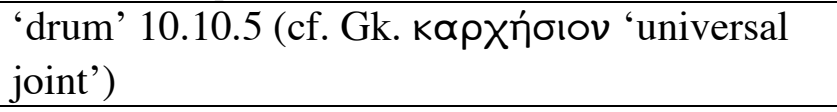 \\
\hline anteris & 'stay' 10.11 .9 \\
\hline climacis & 'ladder' 10.11.7-8 \\
\hline pterygoma & 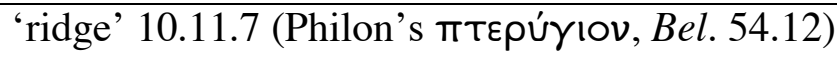 \\
\hline
\end{tabular}

B. Greek terms with explanation or gloss:

\begin{tabular}{|c|c|}
\hline peritreti & $\begin{array}{l}\text { tabulae, quae sunt in summo et in imo capituli } \\
\text { peritretique vocantur } 10.10 .2 \text {; cf. } 10.11 .4\end{array}$ \\
\hline chele & $\begin{array}{l}\text { cheles, sive manucla dicitur10.10.4 ('trigger'); } \\
\text { but knowledge of meaning 'slider' assumed at } \\
10.11 .7 \text { (ei membro, quod Graeci } \times \eta \lambda \eta ́ v ~ v o c a n t)\end{array}$ \\
\hline chelonium & $\begin{array}{l}\text { supra minorem columnam chelonium, sive } \\
\text { pulvinus dicitur } 10.10 .5 \text { ('pillow', 'bolster'; but } \\
\text { no gloss at10.10.4 'block', or } 10.11 .8 \text { 'slider') }\end{array}$ \\
\hline anatonus & $\begin{array}{l}\text { si capitula altiora quam erit latitudo facta fuerint, } \\
\text { quae anatona dicuntur } 10.10 .6\end{array}$ \\
\hline catatonus & $\begin{array}{l}\text { si minus altum capitulum fuerit, quod catatonum } \\
\text { dicitur } 10.10 .6\end{array}$ \\
\hline basis & ...quae appellatur દ̇oxópa 10.11.9; cf. 10.10.4 \\
\hline
\end{tabular}

C. Latin terms with Greek equivalent or gloss:

\begin{tabular}{|c|c|}
\hline cuneoli ferrei & 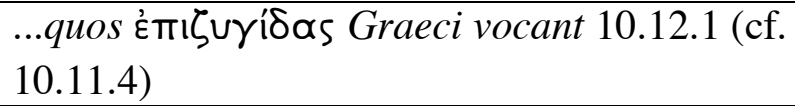 \\
\hline canaliculus & ...qui graece oũpı $\xi$ dicitur 10.10 .3 \\
\hline posterior minor columna & $\begin{array}{l}\text {...quae graece dicitur ơvтíßaoıs 10.10.5; cf. } \\
10.11 .9 \text { for the sense 'counter-base' }\end{array}$ \\
\hline scutula & ... quae graece пврі́трптоs appellatur 10.11 .4 \\
\hline
\end{tabular}


D. Latin terms without explanatory gloss:

\begin{tabular}{|l|l|}
\hline capitulum & 'frame' \\
\hline foramen & 'hole' \\
\hline antefixum & 'cross-piece' 10.10.4 \\
\hline subiectio & 'stay' 10.10.5 (= Heron's óvtnpeíoıov) \\
\hline bracchium & 'arm' \\
\hline modiolus & 'washer' \\
\hline canalis fundus & 'slider' 10.10.4 \\
\hline mensa & 'table' \\
\hline
\end{tabular}

\section{Conclusion}

Let me now attempt to sum up the results of this study and draw some general conclusions. First, the sources we have considered provide ample evidence of the role of technological development in stimulating the creation of technical terminology. The invention of artillery, and of torsion artillery in particular, prompted the creation of an extensive and detailed terminology that was transmitted by practitioners over several centuries both orally and in written form. Terminological developments -- whether the coining of new terms such as тврі́трптоv or shifts in the meaning of existing terms (such as Philon's use of દ̇тıотрофń or

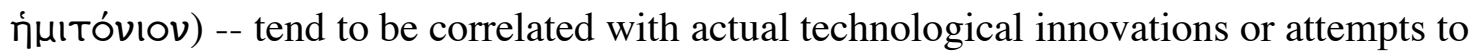
introduce them. Second, it is remarkable that, despite a certain amount of variation, the terminology of artillery construction remained relatively stable and consistent from the third century BC through the time of Vitruvius (cf. Marsden 1971: 157). Here there is a contrast with other fields such as medicine, where the situation down to the first century AD has been characterized as one 'bordering on terminological anarchy'. ${ }^{32}$ The stability of the terminology of artillery construction is in part a reflection of the lack of any fundamental technological advances during the period we have considered: there was certainly no new discovery comparable to that of torsion artillery between the third century BC and the first century AD. But another factor was also important: a consistent, stable terminology facilitates communication between practitioners and the transmission of knowledge, by making it possible to refer to the objects of a TÉXVП in a precise way with just a single word or combination of words. Technical terminology

\footnotetext{
${ }^{32}$ So Lloyd (1983: 163) on the development of Greek anatomical terminology down to the beginning of the second century AD. In this case, of course, there was controversy not only about what names to give to certain structures, but also about what structures should be given names at all; cf. next $\mathrm{n}$.
} 
is, above all, a means of communication, and the relative lack of variation in the terminology of artillery construction is an indication of just how useful such a means could be in the ancient world. Finally, while the sources we have considered provide ample evidence of the freedom with which Greek engineers coined new terms and gave new senses to old ones to refer to the objects and practices of their TÉ $\chi \vee \eta$, they do not offer any examples of the creation of theoretical terms, i.e. terms referring to abstract concepts or entities whose scope of reference is stipulated by precise definitions or by their role in a system of explanations. The creation of such terminology, though sometimes inspired by technological developments, was not a direct response to them; rather, it was a response to the need to communicate new concepts that had been created in a context of theoretical investigation. ${ }^{33}$ For insight into the motives leading to the creation of this kind of technical terminology and its modalities we must turn to sources other than those considered in this study. ${ }^{34}$

\section{References}

Callebat, L. / Fleury, P. (1995): Dictionnaire des termes techniques du De architectura de Vitruve, Hildesheim: Olms - Weidmann.

Callebat, L. / Fleury, P. (edd.) (2003): Vitruve, De l'architecture. Livre X, Paris: Les Belles Lettres.

Diels, H. (1924): Antike Technik, Leipzig: Teubner.

Fögen, T. (2002): 'Der Umgang mit griechischen Termini in lateinischen Fachtexten: Versuch einer Systematisierung', in: Bogdan Kovtyk / Hans-Joachim Solms / Gerhard Meiser

\footnotetext{
${ }^{33}$ As an example of the use of a term drawn from the technological sphere in anatomy we may consider Herophilus' application of a the term $\lambda \tilde{n} v o s$ ('vat', 'press') to refer to a particular structure in the brain known as the torcular Herophili (Russo 2004:150-1). As Russo remarks (2004: 153): 'When Herophilus picks from the continuous and enormously complex structure that is the circulatory system those particular features that warrant a specific name (such as calamus or torcular) in view of his physiological and pathological purposes, he is creating new concepts. $\mathrm{He}$ is in fact inaugurating a new discipline in which not only the words but even the corresponding concepts are conscious creations'. On the importance of theoretical terms in Hellenistic mathematics and science, and the ways in which they were coined, see Russo (2004: 179-85).

${ }^{34}$ I would like to express special thanks to Thorsten Fögen for his comments and for sharing offprints with me, and to Jürgen Renn, Director at the Max Planck Institute for the History of Science, Berlin, for providing crucial institutional support during the writing of this paper.
} 
(edd.), Geschichte der Übersetzung. Beiträge zur Geschichte der neuzeitlichen, mittelalterlichen und antiken Übersetzung, Berlin: Logos Verlag, 259-276.

Landels, J. G. (1978): Engineering in the ancient world, Berkeley: University of California Press.

Lloyd, G. E. R. (1983): Science, folklore and ideology: studies in the life sciences in ancient Greece, Cambridge: Cambridge University Press.

Marsden, E. W. (1969): Greek and Roman artillery: historical development, Oxford: Oxford University Press.

Marsden, E. W. (1971): Greek and Roman artillery: technical treatises, Oxford: Oxford University Press.

Russo, L. (2004): The forgotten revolution: how science was born in 300 BC and why it had to be reborn, Berlin: Springer Verlag. 